\title{
When culture and mathematics meet: A reflection on a study of Hanoi ancient houses
}

\author{
Tran Ha Anh \\ Foreign Trade University \\ 91 Chùa Láng, Láng Thượng, Dong Da District, Hanoi 100000, Vietnam \\ Email: haanhtr@ftu.edu.vn
}

Hanoi, Sept. 24, 2019

In the age of rapid urbanization and digitization, it is astounding that we can still find in Vietnam, especially around its capital city Hanoi, remnants of the thousand years of Chinese influence, a century of French colonialism, and over two decades of war against the Americans.

While the modern streets are heavily imprinted with the signature style of the French and the European, the Hanoi Old Quarter remains a mystery - especially to Hanoians - as we have been so familiar with it that its existence has been taken for granted. Our minds only begin to spin with puzzles when some foreigners ask why the tube houses in the Old Quarter were built as such and why people still have Chinese signs on their walls.

We can find an answer by looking into research on culture, and this particular work caught my interest due to my background as an economics student - "Cultural evolution in Vietnam's early 20th century: a Bayesian networks analysis of Franco-Chinese house designs" [1]. It is a fusion of culture and mathematics. It creates a shared space for social scientists and culturalists and even artists. And most importantly, by walking through the old houses in Hanoi, the authors have opened up many new doors to the research world.

First, regarding its approach on the matter of cultural evolution, the authors did a good job at pointing out the components of Vietnamese houses' façade and structure: The French-styled columns and shuttered windows, Confucian scrolls, Taoist yin-yang sign, and the Buddhist Lotus Sculpture. It makes us realize a lot of little things that are just there, especially when people often mistake Confucianism with Taoism and just put them into the same category of Chinese culture. The study summarizes the three major periods of French influence over Hanoi architecture, thereby clearing up any questions for someone who lacks a background in architecture.

Second, coming back to the matter of methods, the study reintroduces the readers to Bayes Theorem and how it can be applied to research about non-economic matters [2]. The in-depth Literature Review section portrays how flexible Bayes' theorem can be used to calculate/analyze different aspects of life - from education, crime to culture and religion. This has opened our eyes and made us read into other studies that employ the same 
methods [3]. Yet, it is quite unfortunate that this kind of paper - which touches on Vietnam's rich history and uses a unique statistical approach - is relatively rare.

The result of the Bayesian model indicates a strong influence of Buddhism over the decorations of the house façade - which is not a big surprise, knowing that most Vietnamese people are Buddhist. However, the authors did make a very convincing explanation for these results:

1. Chinese and Confucian presence started to wane when the French arrived and began its colonial era.

2. The French architects in charge at the time may have been influenced by Buddhism during their work with the École Française d'Extrême-Orient (EFEO) and with the restoration of Vietnamese antiquities.

Last, the paper comes to the conclusion with what we believe is its strongest argument - a picture of the old houses' façade in Hanoi. It represents many different architecture styles: the Chinese characters (phoenix), the two lotus flowers on the top columns, the European art décor window and balcony iron railings, the French shuttered windows. This painting has made the conclusion more resounding to the readers, making them "see" exactly what the paper is trying to portray.

Like I have mentioned above, this paper has opened up a lot of doors for readers to the research worlds in general and research on culture and religion in particular. No longer will we be limited to qualitative methods when studying these matters, and we do hope that our fellow readers will have the same understanding after reading this article.

\section{References:}

[1] Vuong, Q. H., Khiem, B. Q., La, V. P., Vuong, T. T., Ho, T. M., Nguyen, H. T., ... Ho, T. M. (2019). Cultural evolution in Vietnam's early 20th century: a Bayesian networks analysis of Hanoi Franco-Chinese house designs. Social Sciences and Humanities Open, 1(1), 100001, DOI: 10.1016/j.ssaho.2019.100001.

[2] La, V.P, \& Vuong, Q.H. (2019). bayesvl: Visually Learning the Graphical Structure of Bayesian Networks and Performing MCMC with 'Stan.' The Comprehensive $R$ Archive Network (CRAN). Retrieved from <https://cran.rproject.org/web/packages/bayesvl/index.html> (version 0.8.5) (September 22, 2019).

[3] Vuong Q.H., La V.P., Vuong T.T., Nguyen V.H., Ho M.T., Nguyen T.H.K., Bui Q.K., Ho M.T. (2018). Cultural additivity: Behavioural insights from the interaction of Confucianism, Buddhism, and Taoism in folktales. Palgrave Communications, 4, 143, DOI: 10.1057/s41599-018-0189-2. 